\title{
Geosciences
}

http://dx.doi.org/10.1590/0370-44672019730113

\author{
Eliana Satiko Mano ${ }^{1,3}$ \\ https://orcid.org/0000-0003-0226-124X \\ Laurent Caner ${ }^{2,4}$ \\ https://orcid.org/0000-0001-5618-744X \\ Sabine Petit ${ }^{2,5}$ \\ https://orcid.org/0000-0002-3704-7537 \\ Arthur Pinto Chaves ${ }^{1,6}$ \\ https://orcid.org/0000-0002-9719-2365 \\ 'Universidade de São Paulo - USP, \\ Escola Politécnica, Departamento Engenharia de \\ Minas e de Petróleo, São Paulo - São Paulo - Brasil. \\ ${ }^{2}$ Université de Poitiers, Institut de Chimie des Milieux \\ et Matériaux de Poitiers, IC2MP, UMR- CNRS, \\ Poitiers - France. \\ E-mails: ${ }^{3}$ elli mano@hotmail.com, \\ laurent.caner@univ-poitiers.fr, \\ 5sabine.petit@univ-poitiers.fr, \\ 6arthurchaves@terra.com.br
}

\section{Mineralogical characterization of copper lateritic ore from the Furnas deposit - Carajás, Brazil}

\section{Abstract}

Furnas is a small and not well-known copper sulfide deposit in the northern Carajás mineral province (Pará State, Brazil). Mineralogical and geochemical studies were performed on three weathered samples in order to verify the presence of copper in the lateritic minerals. According to these Cu-bearing minerals (malachite, e.g.), the weathered ore can be exploited. X-ray diffraction (XRD), Scanning Electron Microscopy (SEM) and Fourier Transformed Infrared (FTIR) spectroscopy analyses have shown that the copper is mainly associated to cryptomelane and to clay minerals and, although goethite composes from 40 to $50 \%$ of the samples (weight \%), less than $0.1 \%$ of the total $\mathrm{Cu}$ is associated to it. Based on the results, the weathering sequence could be established; the alteration processes were responsible for the dissolution of the copper primary sulfides; the $\mathrm{Cu}$ released by these sulfides is, afterwards, incorporated in biotites and vermiculites, following the gneiss schistosity. Afterwards, the biotites altered to an interstratified 10-14 $\AA$ (biotite-smectite-vermiculite) and subsequently to an $\mathrm{Al}-\mathrm{Fe}-\mathrm{Cu}$ smectite (nontronite); finally, smectite was altered to kaolinite and the $\mathrm{Cu}$ was leached.

Keywords: Carajás, Furnas deposit, mineral characterization; Cu-bearing minerals, clay minerals.

\section{Introduction}

The mineral province of Carajás is considered one of the most important iron oxide copper gold ore provinces (IOCG) in the world (Teixeira et al., 2010; Groves et al., 2010), often com- pared to the Olympic Dam in Australia (Tallarico et al., 2005); it is located in the eastern part of the Amazon craton in northwestern Brazil. The estimated $\mathrm{Cu}$ resource for all of the Carajás province is around 2 billion metric tons $(\mathrm{Bt})$, with an average $1.4 \mathrm{wt} \%$ of $\mathrm{Cu}$ and 0.28 to $0.86 \mathrm{~g} / \mathrm{t}$ of Au (Moreto et al., 2015), for the sulfide ore.

The Carajás province is formed 
by two tectonic domains: Carajás and Rio Maria, limited by a regional E-W discontinuity (Monteiro et al., 2014). The Rio Maria domain comprehends greenstone belts of the metavolcanic sediments type and mesoarchean magmatism (granites and granodiorites). In addition, the Carajás domain is formed by mesoarchean magmatism, especially granites, gneisses and metavolcanic sediments, without greenstone belt evidences. The Archean basement is covered by Igarapé Salobo-Pojuca and Grão Pará group sediments (amphibolites,

\section{Materials and methods}

Three samples of different $\mathrm{Cu}$ contents were provided by the Vale mining company from the Furnas deposit, a small $\mathrm{Cu}$ target, located in the northern Carajás province (Pará, Brazil).

The sampling was performed by Vale and, according to the chemical compositions (table 1) they refer to the different horizons in the weathered profile.

The chemical composition for the three samples was determined by X-ray fluorescence (XRF) on powered bulk samples with Axios Advanced (PANalytical). Loss on ignition (LOI) values of the bulk samples were obtained from $1 \mathrm{~g}$ of bulk samples dried at $100^{\circ} \mathrm{C}$ and heated at $1020^{\circ} \mathrm{C}$ for two hours; afterwards, the samples were left in a desiccator to cool and later weighed (Dean, 1974). Three samples were separated according to their $\mathrm{Cu}$ grades: $\mathrm{C} 1$ - Low $\mathrm{Cu}$ content $(<1 \%$ of $\mathrm{CuO}), \mathrm{C} 2$ - intermediate $\mathrm{Cu}$ amount $(1-1.5 \%$ of $\mathrm{CuO})$ and $\mathrm{C} 3-$ high $\mathrm{Cu}$ grade $(>1.5 \%$ of $\mathrm{CuO})$.

The samples were treated with a solution of dithionite, tricitrate and sodium bicarbonate (DCB) at $80^{\circ} \mathrm{C}$ for $45 \mathrm{~min}$. to solubilize the Fe oxi-hydroxides (Mehra and Jackson, 1960). The $\mathrm{Cu}$ in solution was determined by ICP to estimate the $\mathrm{Cu}$ associated to the $\mathrm{Fe}$ oxi-hydroxides, such as goethite.

The mineralogical assemblage in the

\section{Results}

\subsection{Samples composition}

According to the XRD and XRF analyses (Table 1), all the three samples exhibited similar mineralogy, essentially composed of quartz, clay minerals and Fe and Mn oxide/hydroxide (goethite and cryptomelane). Sample C1 exhibited larger amounts of quartz than the other samples $(30 \mathrm{wt} \%)$ whereas its contents of quartzites and banded iron formations BIFs). Finally, marine and fluvial clastic sediments of the Águas Claras Formation are discordantly deposited above it (Schwarz and Frantz, 2013; Moreto et al., 2015). Lately, intrusions of mafic, ultramafic rocks and granites followed by tectonic events reactivated old faults resulting in low-grade metamorphism (greenschist facies) and metasomatism/ hydrothermalism events. These hydrothermal events led to the formation of the primary $\mathrm{Cu}$-sulfide mineralizations. Weathering and hydrothermal

bulk samples was identified by randomly oriented X-ray powder diffraction. X-ray diffraction (XRD) patterns were recorded on a Bruker D8 Advance diffractometer $(\mathrm{Cu} \mathrm{K} \alpha$ radiation - 40 kV, 40 mA- Lynx eye detector) from 2 to $65^{\circ} 2 \theta$ with steps of $0.025^{\circ} 2 \theta$ and a counting time per step of $115 \mathrm{~s}$ (converted from scanning mode).

The clay minerals of the samples were studied after the extraction of the $<2 \mu \mathrm{m}$ fractions. Initially, the samples were dispersed into distilled water and wet sieved at $50 \mu \mathrm{m}$. The coarse material $(>50 \mu \mathrm{m})$ was discarded and the fine fractions $(<50 \mu \mathrm{m})$ were saturated with $\mathrm{NaCl} 1 \mathrm{~mol}^{-1} \mathrm{~L}^{-1}$ to deflocculate the particles (Moore and Reynolds, 1989). The clay fractions $(<2 \mu \mathrm{m})$ were separated by centrifugation and studied (Mano et al., 2015). Afterwards, the $<2 \mu \mathrm{m}$ fraction was separated into five sub-fractions: $<0.05 \mu \mathrm{m}, 0.05$ to $0.1 \mu \mathrm{m}, 0.1$ to $0.2 \mu \mathrm{m}, 0.2-1 \mu \mathrm{m}$ and $1-2 \mu \mathrm{m}$; each size fraction was studied in detail. The different sub-fractions were separated by successive centrifugation cycles at different relative centrifugal forces (Laird et al., 1991). The bulk $<2 \mu \mathrm{m}$ and the sub-micrometric fractions were flocculated, saturated with $\mathrm{CaCl}_{2} 0.5 \mathrm{~mol}$. $\mathrm{L}^{-1}$ and washed with distilled water by dialysis to remove the excess of salts. XRD patterns were obtained from oriented Ca-saturated clay dried at room alterations of these sulfides lead to the $\mathrm{Cu}$-bearing lateritic minerals formation.

Based on the studies by Oliveira et al. (1995), Toledo-Groke et al. (1987) and Veiga et al. (1991), which described malachite, cryptomelane, goethite and clay minerals as the main $\mathrm{Cu}$-bearing lateritic minerals in the Salobo deposit, a detailed mineralogical study was conducted on the lateritic samples from the Furnas deposit. According to the results, the lateritic ore from Furnas could also be exploited together with the sulfide ore in order to increase the $\mathrm{Cu}$ recoveries. temperature $(\mathrm{AD})$ and after ethylene glycol (EG) saturation, from 2 to $50^{\circ} 2 \theta$ with steps of $0.025^{\circ} 2 \theta$ and a counting time per step of $192 \mathrm{~s}$ (converted from scanning mode).

Fourier transformed infrared (FTIR) spectroscopy was used to specify the crystal chemistry of the Cu-bearing clay minerals. Mid infrared analyses (MIR) were performed in transmission mode using a Nicolet Magna-IR 760 spectrometer in the $400-4000 \mathrm{~cm}^{-1}$ range with a $2 \mathrm{~cm}^{-1}$ resolution. The spectra were obtained from pressed $\mathrm{KBr}$ pellets, prepared by mixing $1 \mathrm{mg}$ of sample with $150 \mathrm{mg}$ of $\mathrm{KBr}$ and pressing at $10 \mathrm{t} \mathrm{cm}^{-2}$ and drying overnight at $110^{\circ} \mathrm{C}$. The infra-red spectra were analyzed using the Omnic software.

The $<2 \mu \mathrm{m}$ sub-fractions were mounted in polished section slides, coated with metallic carbon to be analyzed in a scanning electron microscopy (SEM) coupled to EDX (energy dispersive X-ray spectroscopy). The EDX microanalyses were performed both to distinguish the clay minerals composition and to quantify the $\mathrm{Cu}$ contents associated to them. The microanalyses were performed on an INCA Energy 300 device from Oxford Instruments, with a $\mathrm{Si}(\mathrm{Li})$ detector coupled to a SEM LEO 440 - Leica installed at the Instituto de Geociências at the Universidade de São Paulo - Brazil. goethite and cryptomelane were the lowest $(<45 \%$ and $<3 \%$ respectively). Sample $\mathrm{C} 3$, on the other hand, exhibited high contents of $\mathrm{Fe}$ and $\mathrm{Mn}$ oxides/hydroxides $(<55 \%$ and $10 \%)$ and low amounts of quartz (<15\%). Sample C2 exhibited an intermediate composition, with nearly $20 \%$ of quartz, $50 \%$ of goethite and $<5 \%$ of cryptomelane. For all the samples, the clay mineral contents represented between 20 to $30 \%$ (wt \%). In the Furnas deposit, the goethite contents vary between 40 and $55 \%$ of the bulk samples. Manganese and copper contents showed the same behavior, suggesting that part of the $\mathrm{Cu}$ was associated to $\mathrm{Mn}$ as cryptomelane. 
Table 1 - Chemical composition of the samples (oxides weight \%).

\begin{tabular}{c|c|c|c}
\hline Samples & $\mathrm{C} 1$ & $\mathrm{C} 2$ & $\mathrm{C} 3$ \\
\hline $\mathrm{MgO}$ & 1.93 & 1.60 & 1.36 \\
\hline $\mathrm{Al}_{2} \mathrm{O}_{3}$ & 9.04 & 8.68 & 8.73 \\
\hline $\mathrm{SiO}_{2}$ & 37.0 & 28.6 & 24.0 \\
\hline $\mathrm{K}_{2} \mathrm{O}$ & 3.12 & 2.90 & 2.11 \\
\hline $\mathrm{MnO}$ & 0.52 & 1.06 & 2.22 \\
\hline $\mathrm{Fe}_{2} \mathrm{O}_{3}$ & 37.8 & 45.8 & 47.3 \\
\hline $\mathrm{CuO}$ & 0.79 & 1.30 & 1.69 \\
\hline $\mathrm{LOI}$ & 8.84 & 9.50 & 11.69 \\
\hline total & 99.0 & 99.4 & 99.1 \\
\hline & & &
\end{tabular}

\subsection{Clay minerals study}

The XRD patterns of the $<2 \mu \mathrm{m} \mathrm{Ca}$ saturated fractions of the three samples (Figure 1), exhibited peaks at $d_{001 \mathrm{AD}}=7.1 \AA$ and $d_{002 \mathrm{AD}}=3.6 \AA$ which did not swell after EG treatment, being attributed to kaolinite. Peaks at $d_{001 \mathrm{AD}}=10.0 \AA$, $d_{002 \mathrm{AD}}=5.0 \AA$ and $d_{003 \mathrm{AD}}=3.4 \AA$, which did not shift after EG treatment indicated the presence of mica-illite. Finally, a peak at $d_{001 \mathrm{AD}}=14.4 \AA$, which displaced to $d_{001 \mathrm{EG}}=16.5 \AA$ after EG treatment, revealed the presence of swelling clay minerals such as smectite. Figure $1 \mathrm{~b}$ detailedly showed a low-angle shoulder at $d_{001 \mathrm{EG}}=11.6 \AA$, particularly for sample $\mathrm{C} 3$, highlighted after the EG solvatation. This reflection is attributed to an interstratified clay mineral containing mica and an expandable layer

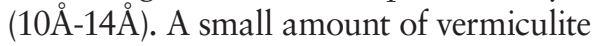
was also observed in sample $\mathrm{C} 3$, thanks to the reflection at $14.6 \AA$ (Figure $1 \mathrm{~b}$ ), which did not shift after EG treatment.

The finest fractions $(<0.05$ and $0.05-0.1 \mu \mathrm{m}$ ), which represent from 15 to
$20 \%$ (wt $\%$ ) of the samples, concentrated smectite; while the coarsest fractions $(0.1-2 \mu \mathrm{m})$, which vary from 5 to $10 \mathrm{wt} \%$ of the samples, concentrated mica, kaolinite and mixed layers (Figure 2). Samples $\mathrm{C} 1$ and $\mathrm{C} 2$, in the fractions between 1 and $2 \mu \mathrm{m}$, exhibited a $d_{001}$ at $12.4 \AA$ that displaced to $12.9 \AA$ after EG solvatation (Figure 2d), indicating an interstratification of mica and an expandable layer. This mixed layer is almost absent in sample C3, as noticed in Figure 2d.

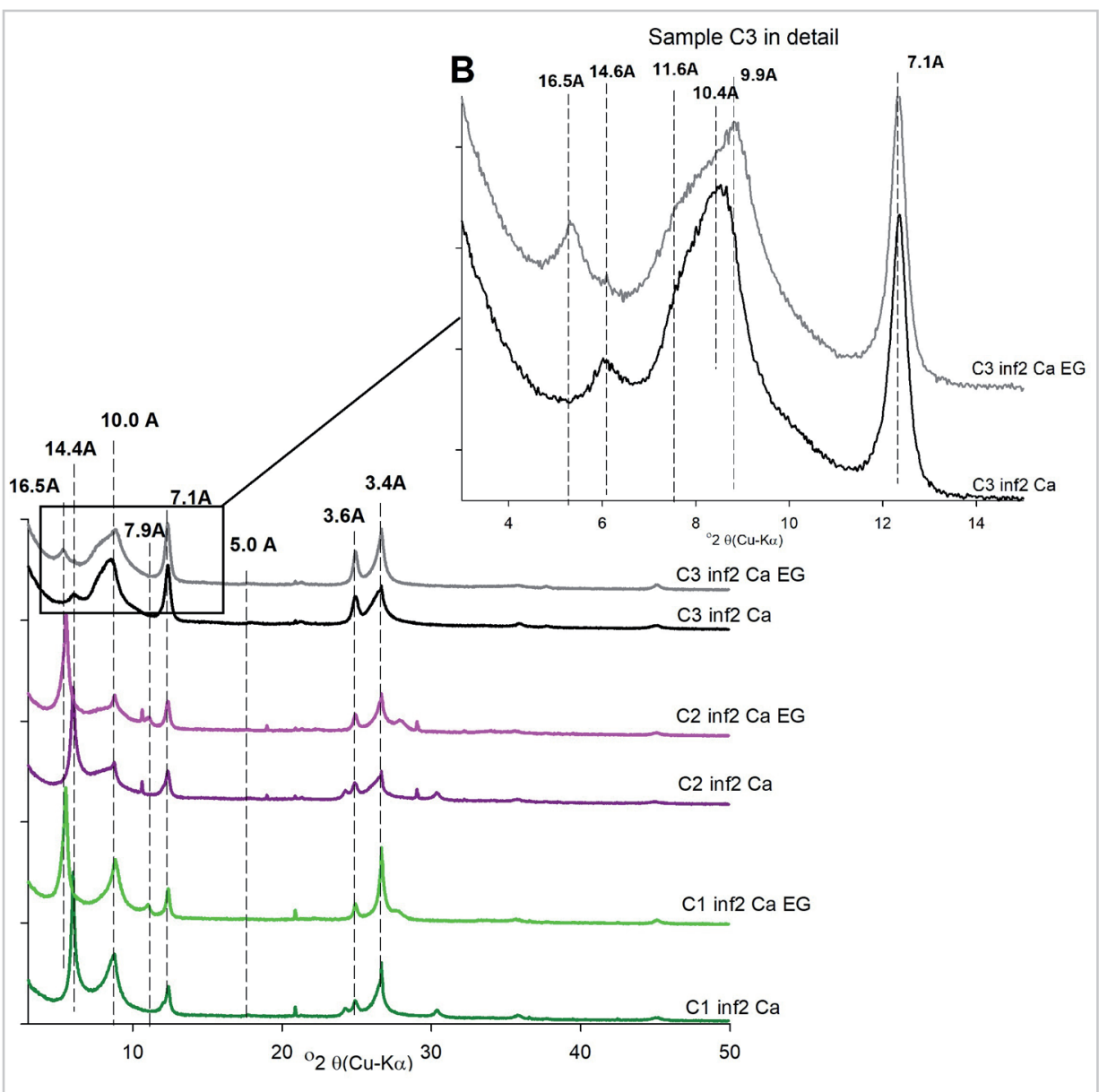

Figure 1 - X-ray diffraction patterns for the blended samples saturated with Ca and after ethylene glycol (EG) solvatation. Sample C3 is shown in detail - B. 

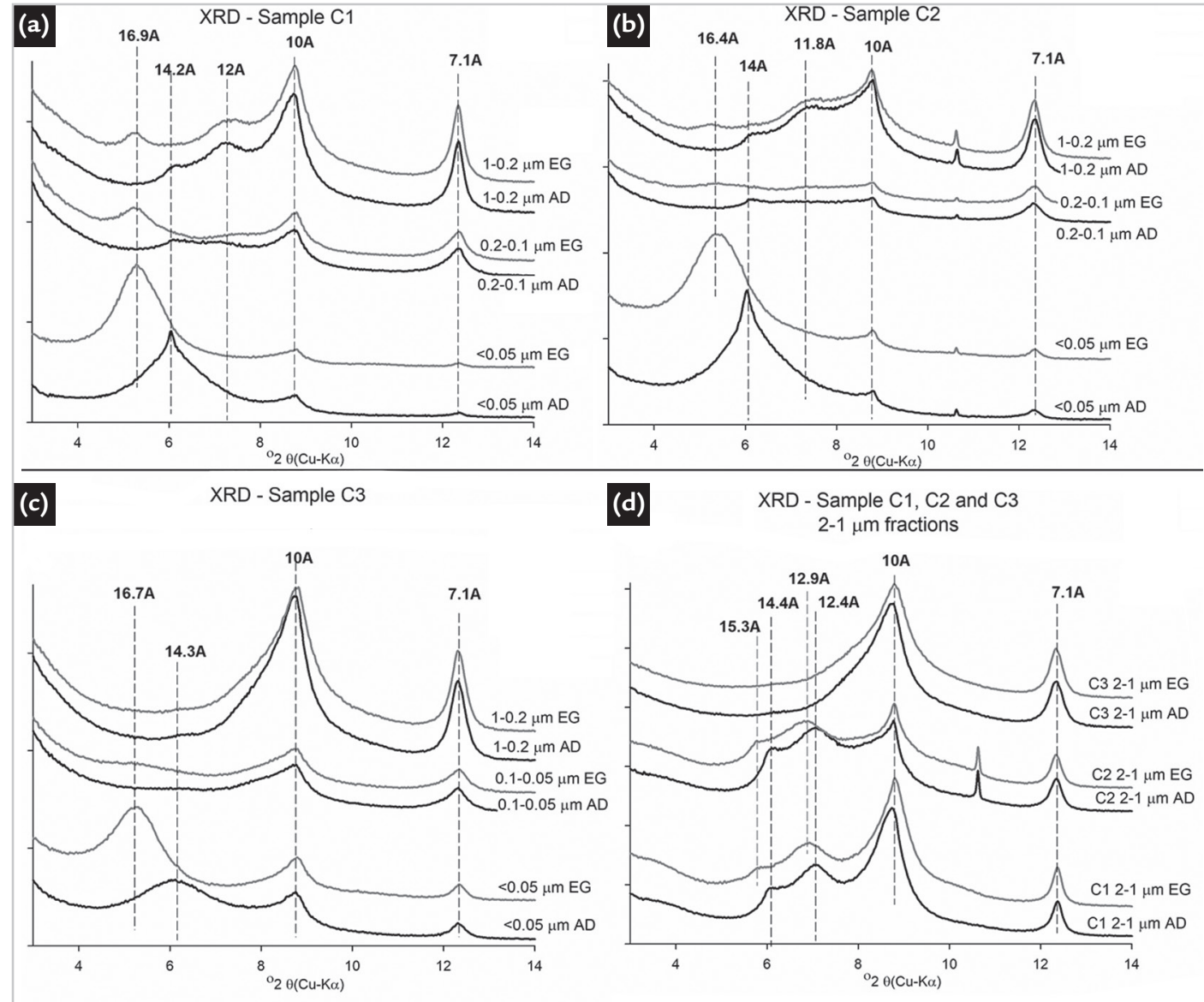

Figure 2 - X-ray diffraction patterns for the three samples $C 1, C 2$ and $C 3$ (a, b and c)

in air-dried $(A D)$ and after ethylene glycol solvatation (EG). Figure $2 \mathrm{~d}$ compares the coarse fraction of the three samples.

\subsubsection{Scanning electron microscopy and X-ray dispersion energy analyses}

EDX microanalyses for the ing between biotite and smectite, as $<2 \mu \mathrm{m}$ size fractions of samples $\mathrm{C} 1$, shown in the ternary diagram $\mathrm{Al}_{2} \mathrm{O}_{3}$ / $\mathrm{C} 2$ and $\mathrm{C} 3$ confirmed the presence of $\mathrm{K}_{2} \mathrm{O} / \mathrm{Fe}_{2} \mathrm{O}_{3}+\mathrm{CuO}+\mathrm{MgO}$ (Figure 3). clay minerals with a composition vary- The microanalyses data plotted in a

ternary diagram of $\mathrm{MgO} / \mathrm{Al}_{2} \mathrm{O}_{3} / \mathrm{Fe}_{2} \mathrm{O}_{3}$ confirmed that smectites in the $<0.05 \mu \mathrm{m}$ size fractions have a composition close to nontronite (Figure 3b).
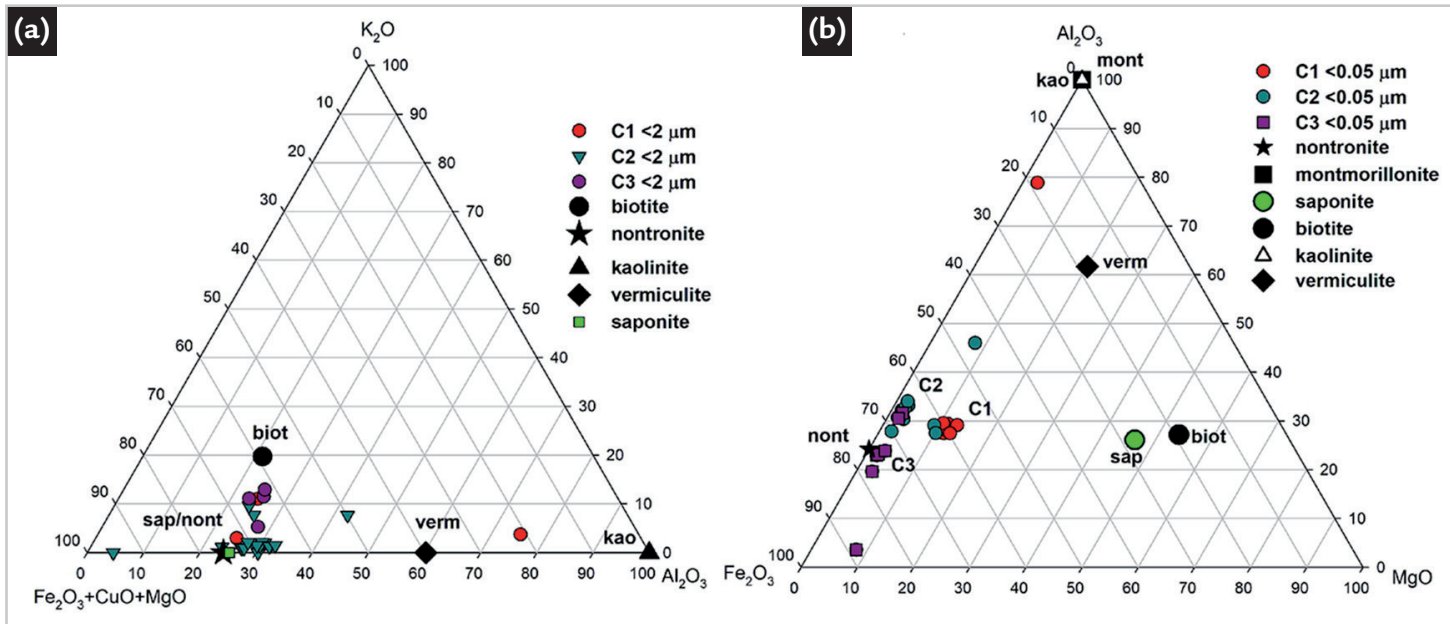

Figure 3 - Ternary diagram for clay mineral particles $<2 \mu \mathrm{m}$ for all samples (a). The theoretical compositions for biotite, nontronite, kaolinite and vermiculite have also been plotted. (b) - Ternary diagram of $<0.05 \mu \mathrm{m}$ size fraction for all samples. Their composition is close to a Fe-rich dioctahedral smectite (Petit et al., 1992).

\subsubsection{Mid infrared results}

Kaolinite was easily identified in the MIR spectra of all size fractions (Figure 4), especially for the $0.1-2 \mu \mathrm{m}$ size fractions through its characteristic
AlAlOH stretching bands ( $v \mathrm{AlAlOH})$ at $3695 \mathrm{~cm}^{-1}, 3669 \mathrm{~cm}^{-1}, 3653 \mathrm{~cm}^{-1}$ and $3620 \mathrm{~cm}^{-1}$ (Farmer, 1974; Madejová et al., 2011). Moreover, the band at
$3596 \mathrm{~cm}^{-1}$, attributed to $v \mathrm{AlFe}^{3+} \mathrm{OH}$ in kaolinite (Petit and Decarreau, 1990; Iriarte et al., 2005), showed that kaolinite contains structural iron. 
The broad absorption band centered at $3420 \mathrm{~cm}^{-1}$, due to water, revealed the presence of smectites. This band is more intense for the $<0.05 \mu \mathrm{m}$ fractions. The observed band at about $3570 \mathrm{~cm}^{-1}$ in the $\mathrm{OH}$ stretching region at 820 and $876 \mathrm{~cm}^{-1}$ in the $\mathrm{OH}$ bending region allowed characterizing iron rich-smectite and, more precisely, Al-nontronite (Petit et al., 2015). There are three possibilities for copper occupation in smectites: i) in vacant sites of octahedral sheets; ii) in hexagonal cavi- ties of the tetrahedral sheets; iii) as exchangeable $\mathrm{Cu}^{2+}$ ion in interlayer sheets. Madejová et al. (1999) and Seiffarth and Kaps (2009) described some changes in $\mathrm{Si}-\mathrm{O}$ vibrations in the MIR region induced by $\mathrm{Cu}$ migration in smectites structures. Seiffarth and Kaps (2009) observed a shift from 1050 to $1058 \mathrm{~cm}^{-1}$ of $\mathrm{Si}-\mathrm{OH}$ stretching band resulting from the $\mathrm{Cu}$ migration from the interlayer to the hexagonal cavities of the tetrahedral sheet or to octahedral sites.

Petit et al. (1995) demonstrated that the presence of copper induced changes in absorption bands, such as broadening and loss of resolution of the $3668 \mathrm{~cm}^{-1}$, for synthetic kaolinites, containing from 0.1 to $7 \%$ of $\mathrm{Cu}$. In these synthetic samples, copper was suspected to be in the trioctahedral distribution.

The FTIR spectra of the three samples did not show any evidence of the presence of $\mathrm{Cu}$ in either the smectite or the kaolinite structure. These features might be due to the too low $\mathrm{Cu}$ amounts in the clay minerals to be detected.

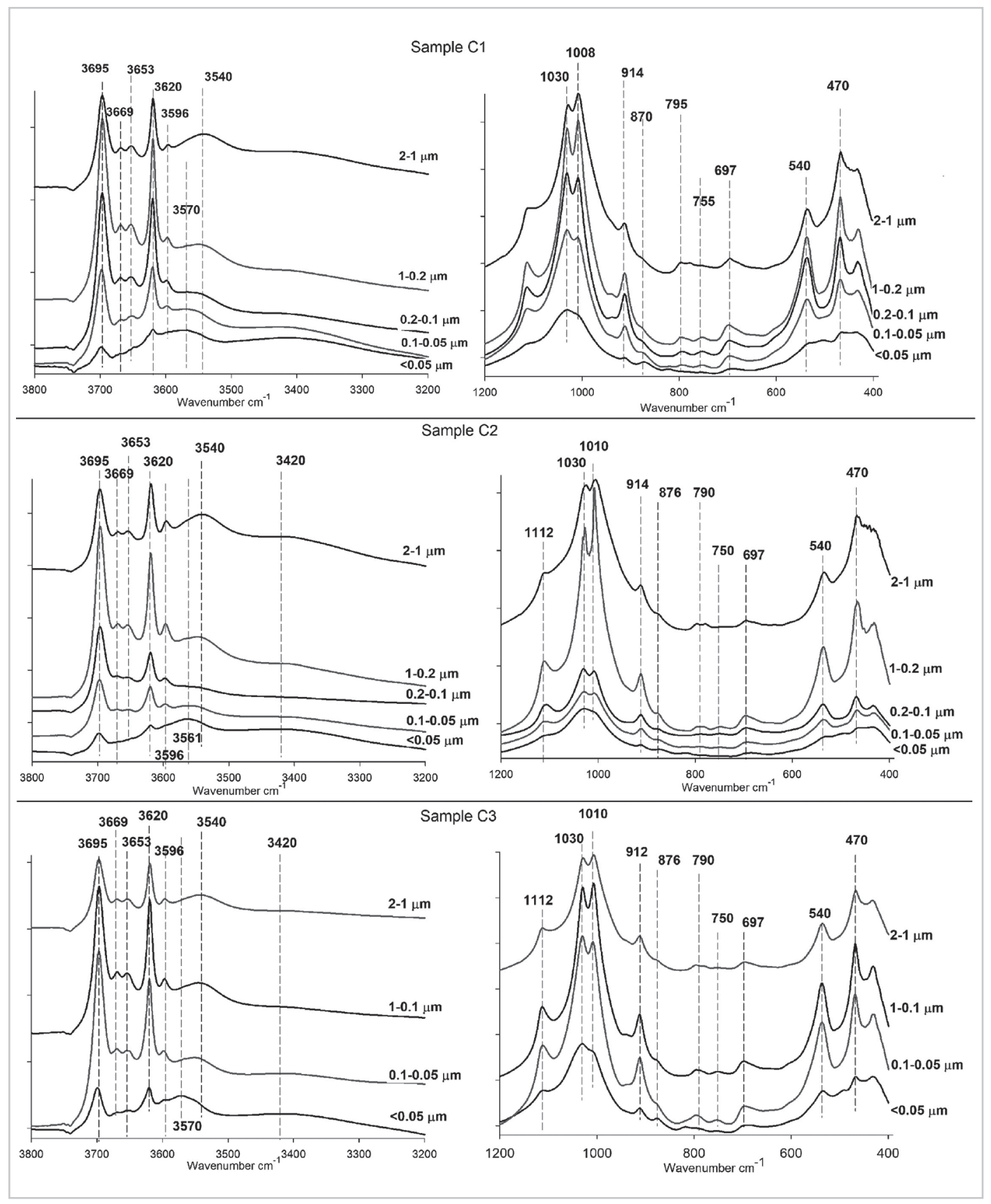

Figure 4 - MIR spectra for all samples.

Chemical analyses by ICP-OES allowed determining the $\mathrm{Cu}$ associations in the $<2 \mu \mathrm{m}$ sub-fractions. The results revealed that $\mathrm{Cu}$ contents are higher in the coarsest size fractions (Table 2), composed mainly of biotite as compared to the finest fractions composed especially of smectite.
Unfortunately, the amounts of 0.05 to $1 \mu \mathrm{m}$ fractions for samples $\mathrm{C} 2$ and C3 were not sufficient to perform the ICP analysis. 
Table 2 - Chemical analyses by ICP for sample C1 (weight \%). ns - no sample.

\begin{tabular}{c|c|c|c|c|c}
\hline Sample & $\mathrm{Cu}(\mathrm{wt} \%)$ & Sample & $\mathrm{Cu}(w \mathrm{w} \%)$ & Sample & $\mathrm{Cu}(\mathrm{wt} \%)$ \\
\hline $\mathrm{C} 1<2 \mu \mathrm{m}$ & 0.623 & $\mathrm{C} 2<2 \mu \mathrm{m}$ & 0.78 & $\mathrm{C} 3<2 \mu \mathrm{m}$ & 1.09 \\
\hline $\mathrm{C} 1<1 \mu \mathrm{m}$ & 0.471 & $\mathrm{C} 2<1 \mu \mathrm{m}$ & $\mathrm{ns}$ & $\mathrm{C} 3<1 \mu \mathrm{m}$ & $\mathrm{ns}$ \\
\hline $\mathrm{C} 1<0.2 \mu \mathrm{m}$ & 0.447 & $\mathrm{C} 2<0.2 \mu \mathrm{m}$ & $\mathrm{ns}$ & $\mathrm{C} 3<0.2 \mu \mathrm{m}$ & $\mathrm{ns}$ \\
\hline $\mathrm{C} 1<0.1 \mu \mathrm{m}$ & 0.265 & $\mathrm{C} 2<0.1 \mu \mathrm{m}$ & $\mathrm{ns}$ & $\mathrm{C} 3<0.1 \mu \mathrm{m}$ & $\mathrm{ns}$ \\
\hline $\mathrm{C} 1<0.05 \mu \mathrm{m}$ & 0.129 & $\mathrm{C} 2<0.05 \mu \mathrm{m}$ & 0.71 & $\mathrm{C} 3<0.05 \mu \mathrm{m}$ & 0.81 \\
\hline
\end{tabular}

\section{Discussion}

In oxidized ores, $\mathrm{Cu}$ is frequently associated to goethite (Oliveira et al., 1995; Veiga et al., 1991; Gerth, 1990; Toledo-Groke et al., 1987; Ildefonse et al., 1986); however, in the Furnas deposit, this element is preferentially associated to cryptomelane, as observed by Mosser and Zeegers (1988) in Burkina Faso (Africa) and Traina and Doner (1985). The chemical analyses (Table 1) performed in this study also confirmed this assumption. Even though Fe-oxides/hydroxides represented from 40 to $55 \%$ (mass) of the samples, less than $0.1 \%$ of $\mathrm{Cu}$ is associated to them, according to the ICP analyses of the solutions from the DCB treatment. In fact, in the Furnas deposit,

\section{Conclusions}

In the Furnas deposit, as well as in the Burkina Faso deposit, $\mathrm{Cu}$ is mainly assigned to cryptomelane instead of goethite, as observed at the Salobo deposit. Expressive $\mathrm{Cu}$ amounts were

\section{Acknowledgments}

This study has been supported by CNPq (Conselho Nacional de Desenvolvimento Científico e Tecnológico) - Project Ciências Sem Fronteiras: 249132/2013-3 and ITV - Instituto Tecnológico Vale. The authors also thank Elisabeth Fonseca and
$\mathrm{Cu}$ is approximately partitioned as $50 \%$ in cryptomelane and $50 \%$ in the clay minerals. Concerning the clay minerals, biotite followed by mixed layers biotite/ vermiculite or biotite/smectite exhibited the highest contents of $\mathrm{Cu}$. Smectite (mainly nontronite) revealed the lowest $\mathrm{Cu}$ content (Table 2). FTIR from the clay fraction showed that copper is not associated to smectite as structural cation or as interlayer cation, since only $0.01 \mathrm{wt} \%$ of $\mathrm{Cu}$ is exchangeable, as also registered by Toledo-Groke et al., (1987).

Petit et al. (1992) showed that smectites from the Salobo deposit exhibited a nontronite composition. Furnas profile is a typical weathering profile found in the
Carajás Province, similar to the Salobo deposit (Ildefonse et al., 1986; ToledoGroke at al., 1987 and Veiga et al., 1991) and also resembling the Burkina Faso deposit (Africa) described by Mosser and Zeegers, (1988). The alteration processes were responsible for the dissolution of primary sulphides. The Cu released by sulfide dissolution is afterwards incorporated by biotites and vermiculites from the gneisses, according their schistosity (Toledo-Groke et al., 1987). The Cu-rich biotites altered to an interlayered clay mineral of 10-14 $\AA$ (biotite-smectite-vermiculite) and subsequently to an Al-Fe-Cu smectite (nontronite); finally, smectite was transformed into a kaolinite depleted in $\mathrm{Cu}$. determined in interlayered clay minerals, possibly a biotite-vermiculite type. Unfortunately, the copper associated to clay minerals is not easy to recover, even in an acid leaching route; there- fore, copper behavior in the weathering environment demands more studies in order to completely understand the geochemical fixing process in the lateritic minerals.
Antonio Clareti, geologist and engineer, respectively, from VALE. One of the authors, E. Mano acknowledges The Mineralogical Society of Great Britain and Ireland (Clay Minerals Group) for a student travel grant, which allowed her to present these results at the $16^{\text {th }}$ International Clay Conference, held in Granada - Spain in July, 2017. The others authors also acknowledge the financial support from European Union (ERDF) and "Région Nouvelle Aquitaine".

\section{References}

DEAN, W. E. Determination of carbonate and organic matter in calcareous sediments and sedimentary rocks by loss on ignition: comparison with other methods. Journal of sedimentary petrology, v. 44, n. 1, p. 242-248, 1974.

FARMER, V. C. (ed.) The Infrared spectra of minerals. London: Mineralogical Society, 1974. (Mineralogical Society Monograph, 4).

GERTH, J. Unit-cell dimensions of pure and trace metal-associated goethites. Geochimica et Cosmochimica Acta, v. 54, n. 2, p. 363-371, 1990.

GROVES, D. I.; BIERLEIN, F. P.; MEINERT, L. D.; HITZMAN, M. W. Iron Oxide Copper-Gold (IOCG) deposits through earth history: implications for origin, lithospheric setting, and distinction from other epigenetic iron oxide deposits. Economic Geology, v. 105, n. 2, p. 641-654, 2010.

ILDEFONSE, P.; MANCEAU, A.; PROST, D.; GROKE, M. C. T. Hydroxy-Cu-vermiculite formed by the weathering of Fe-biotites at Salobo, Carajás, Brazil. Clays and Clay Minerals, v. 34, n. 3, p. 338-345, 1986.

IRIARTE, I.; PETIT, S.; HUERTAS, F. J.; FIORE, S.; GRAUBY, O.; DECARREAU, A.; LINARES, J. Synthesis of 
kaolinite with a high level of $\mathrm{Fe}^{3+}$ for $\mathrm{Al}$ substitution. Clays and Clay Minerals, v. 53, n. 1, p. 1-10, 2005.

LAIRD, D. A.; BARAK, P.; NATER, E. A.; DOWDY, R. H. Chemistry of smectitic and illitic phases in inter- stratified soil smectite. Soil Sci. Soc. Am. J., v 55, n. 5, p.1499-1504, 1991.

MADEJOVÁ, J.; BALAN, E.; PETIT, S. Application of vibrational spectroscopy to the characterization of phyllosilicates and other industrial minerals. In: EMU Notes in Mineralogy. [S. 1.]: European Mineralogical Union, 2011. v. 9, cap. 6, p. 171-226.

MADEJOVÁ, J.; ARVAIOVÁ, B.; KOMADEL, P. FTIR spectroscopic characterization of thermally treated $\mathrm{Cu}^{2+}$ $\mathrm{Cd}^{2+}$, and $\mathrm{Li}^{+}$montmorillonites. Spectrochimica Acta Part A: Molecular and Biomolecular Spectroscopy, v. 55, n. 12, p. 2467-2476, 1999.

MANO, E. S.; CANER, L.; CHAVES, A. P. Metodology for laterítics Cu-bearing clay minerals characterization. Holos, v. 31, n. 7, p. 3-12, 2015.

MEHRA, O. P.; JACKSON, M. L. Iron oxide removal from soils and clays by a dithionite-citrate system buffered with sodium bicarbonate. Clays and Clay Minerals, v. 7, p. 317-327, 1960.

MONTEIRO, L. V. S.; XAVIER, R. P.; SOUZA FILHO, C. R.; MORETO, C. P. N. Metalogênese da Província Carajás. In: SILVA, M. G.; ROCHA NETO, M. B.; JOST, H.; KUYUMJIAN, R. M. (org.). Metalogênese das províncias tectônicas brasileiras. Belo Horizonte: CPRM, 2014. p. 43-92.

MORETO, C. P. N.; MONTEIRO, L. V. S.; XAVIER, R. P.; CREASER, R. A.; DUFRANE, S. A.; TASSINARI, C. C. G.; SATO, K.; KEMP, A. I. S.; AMARAL, W. S. Neoarchean and paleoproterozoic Iron Oxide-Copper-Gold events at the Sossego Deposit, Carajás Province, Brazil: Re-Os and U-Pb Geochronological Evidence. Economic Geology, v. 110, n. 3, p. 809-835, 2015.

MOORE, D. M.; REYNOLDS Jr., R. C. X-ray diffraction and the identification and analysis of clay minerals. University Press: Oxford, 1989.

MOSSER, C.; ZEEGERS, H. The mineralogy and geochemistry of two copper-rich weathering profiles in Burkina Faso, West Africa. Journal of Geochemical Exploration, v. 30, n. 1-3, p. 145-166, 1988.

OLIVEIRA, S. M. B.; CARVALHO E SILVA, M. L. M.; TOLEDO, M. C. M. The role of residual 2:1 phyllosilicates in lateritic metallogenesis: $\mathrm{Ni}$ and $\mathrm{Cu}$ deposits in Serra dos Carajás, Brazilian Amazonia. Geochim. Brasil, v. 9, n. 2, p. 161-171, 1995.

PETIT, S.; DECARREAU, A.; GATES, W.; ANDRIEUX, P.; GRAUBY, O. Hydrothermal synthesis of dioctahedral smectites: the Al-Fe ${ }^{3+}$ chemical series. Part II: Crystal-chemistry. Applied Clay Science, v. 104, p. 96-105, 2015.

PETIT, S.; DECARREAU, A.; MOSSER, C.; EHRET, G.; GRAUBY, O. Hydrothermal synthesis $\left(250^{\circ} \mathrm{C}\right)$ of copper-substituted kaolinites. Clays and Clay Minerals, v. 43, n. 4, p. 482-494, 1995.

PETIT, S.; PROT, T.; DECARREAU, A.; MOSSER, C.; TOLEDO-GROKE, M. C. Crystallochemical study of a population of particles in smectites from a lateritic weathering profile. Clays and Clay Minerals, v. 40, n. 4, p. 436-445, 1992.

PETIT, S.; DECARREAU, A. Hydrothermal $\left(200^{\circ} \mathrm{C}\right)$ synthesis and crystal chemistry of iron-rich kaolinites. Clay Minerals, v. 25, n. 2, p. 181-196, 1990.

SCHWARZ, M.; FRANTZ, J. Depósito de Cu-Zn Pojuca Corpo Quatro: IOCG ou VMS? Pesquisas em Geociências, v. 40, n. 1, p. 5-19, 2013.

SEIFFARTH, T.; KAPS, C. Structural characterization of $\left(\mathrm{Cu}^{2+}, \mathrm{Na}^{+}\right)$and $\left(\mathrm{Cu}^{2+}, \mathrm{NH}^{4+}\right)$ exchanged bentonites upon thermal treatment. Clays and Clay Minerals, v. 57, n. 1, p. 40-45, 2009.

TALLARICO, F. H. B.; FIGUEIREDO, B. R.; GROVES, D. I.; KOSITCIN, N.; MCNAUGHTON, N. J.; FLETCHER, I. R.; REGO, J. L. Geology and SHRIMP U-Pb geochronology of the Igarapé Bahia Deposit, Carajás Copper-Gold Belt, Brazil: an archean $(2.57 \mathrm{Ga})$ example of Iron-Oxide $\mathrm{Cu}-\mathrm{Au}-(\mathrm{U}-\mathrm{REE})$ mineralization. Economic Geology, v. 100, n. 1, p. 7-28, 2005.

TEIXEIRA, J. B. G.; LINDENMAYER, Z. G.; SILVA, M. G. Depósitos de óxidos de ferro-cobre-ouro de Carajás. In: BRITO, R. S. C.; SILVA, M. G.; KUYUMJIAN, R. M. (ed.). Modelos de depósitos de cobre do Brasil e sua resposta ao intemperismo. Brasília: CPRM, 2010. p. 11-213. (Programa Geologia do Brasil: Recursos Minerais Série Metalogenia).

TOLEDO-GROKE, M. C.; MELFI, A. J.; PARISOT, J. C. Comportamento do cobre durante o intemperismo das rochas xistosas cupríferas do Salobo 3a, Serra dos Carajás. Geochimica Brasiliensis, v. 1, n. 2, p. 187-200, 1987.

TRAINA, S. J.; DONER, H. E. Co, Cu, Ni, and Ca sorption by a mixed suspension of smectite and hydrous manganese dioxide. Clays and Clay Minerals, v. 33, n. 2, p. 118-122, 1985.

VEIGA, M. M.; SCHORSCHER, H. D.; FYFE, W. S. Relationship of copper with hydrous ferric oxides: Salobo, Carajás, PA, Brazil. Ore Geology Reviews, v. 6, n. 2-3, p. 245-255, 1991.

Received: 2 August 2019 - Accepted: 23 March 2020. 